\title{
Investigating The Effect of Behavioral Intention on E-learning Systems Usage: Empirical Study on Tertiary Education Institutions in Ghana
}

\author{
Kenneth Wilson Adjei Budu ${ }^{1}$ \\ Mu Yinping ${ }^{1}$ \\ Kingsford Kissi Mireku \\ ${ }^{1}$ School of Management and Economics, \\ University of Electronic, Science, \\ and Technology of China (UESTC), China \\ ${ }^{2}$ Information and Software Engineering, \\ University of Electronic, Science, \\ and Technology of China (UESTC), China
}

Doi: $10.2478 / \mathrm{mjss}-2018-0062$

\section{Abstract}

The objective of the study aimed at assessing the relationship that exists between antecedents of behavioral intentions, and how they impact on the usage of E-learning systems in tertiary institutions in Ghana. Empirical data for the study was obtained through a survey from 237 respondents made up of; governing council members, school management members, faculty members, ICT department staff and students from five tertiary education institutions in Ghana. The study developed an extended Technology Acceptance Model (TAM) by incorporating an external variable, self-efficacy. The hypothesized model was examined using Partial Least Squares Structural Equation Modelling (PLSSEM) technique using Smart PLS version 12 software. The paper argues that perceived usefulness, perceived ease of use and self-efficacy influenced individual's behavioral intentions to utilize E-learning systems. However, the findings confirm that, through the mediating role of individuals' behavioral intention to use, self-efficacy is the most influential factor that affects individual's behavioral intentions to utilize E-learning systems in Ghana's tertiary education institutions, relative to perceived usefulness and perceived ease of use. This result implies that self-efficacy is the main behavioral intention factor in determining E-learning system utilization, in Ghana's tertiary education context. This study satisfies or fills an E-learning utilization literature shortfall by the extension of the Technological Acceptance Model (TAM) to investigate antecedents of behavioral intentions and their impact on E-learning systems usage among tertiary education institutions. Also, the study demonstrates the importance of behavioral intention-to-use as playing a full mediating role between self-efficacy and E-learning system usage.

Keywords: E-learning systems Usage, Behavioral Intention Factors, Tertiary Education Institutions, Partial Least Squares (PLS), Developing Countries

\section{Introduction}

E-learning has been defined commonly, as a learning activity that is aided and enhanced through the use of ICTs (Sambrook, 2003). The process of E-learning encompasses a range of activities such as; the use of information communication technologies (ICTs) in supporting learning and teaching, blended learning, as well as acquiring skills and knowledge entirely by the use of the internet. There are many definitions of E-learning. However, this study adopts Jenkins \& Hanson (2003) definition of E-learning, which is, learning that is assisted and given via the application of 
information and communication technologies (ICTs). In other words, E-learning refers to the integration of information telecommunication technology (ICTs) tools into the enhancement, supporting and delivery of knowledge.

To achieve the primary objective of education and the call for increased accessibility to higher education, the implementation of E-learning systems appears to be the way forward for higher education institutions (Alsabswy et al. 2013). E-learning is regarded as a dynamic and immediate learning environment to improve the quality of knowledge acquisition and transfer. It provides the opportunity for learners to interact with each other, accessibility to materials and services for interaction and collaboration (Docimini \& Palumbo, 2013). This contrary to the traditional classroom setup where time and space serves as a restriction to the communication between students and teachers in the learning and teaching processes (Zhang et al. 2012). Addition, E-learning assisted students with the acquisition of unique experiences and capabilities such as interactivity, efficient information retrieval capability, physical mobility and situating of educational activities, selforganized and focused learning (Bidin \& Ziden, 2013). It further provides competitive advantages to lectures and students in learning and training tenacity and a positive attitude towards collaboration and interaction. E-learning offers the opportunity for students to independently study course contents, the sequence and logical order of the study content, and the period to spend on selfeducation, in the absence of time and space barriers (Chen \& Tseng, 2012). Hence, the resolution that E-learning systems serve as a critical facilitator of knowledge diffusion and acquisition in the 21st century and its effect on educational ecologies cannot be underestimated (Aparicio et al., 2016). As the result of the enormous benefits that E-learning systems usage holds for higher education delivery across the world, researchers have developed several models in measuring users' behavioral attitude toward the adoption, use, acceptance and its satisfaction (Chiu et al., 2005).

In anticipation of enjoying all the benefits that come with E-learning systems usage, Farrell \& Isaac (2007) notes that higher education institutions in developing countries are increasingly investing in this initiative. Developing countries such as; Ghana, are benefiting from a $\$ 15.6$ million grant by the African Development Bank (AfDB) for the development and supporting of various Elearning projects and initiatives, such as the African Virtual University for thirty-one affiliated institutions. However according to (Borstorff et al.., 2007), in spite of all the rewards that these education institutions stand to gain in the implementations and use of E-learning systems; most Elearning projects in developing countries have failed to achieve their objectives. A study conducted by Ssekakubo et al. (2011) on the causes of E-learning failures in Africa identified high ICT illiteracy rate among user communities and low comfort levels with technology, and usability issues as some of the reasons E-learning projects are unable to achieve its objectives. This assertion is consistent with Martins \& Kellermans (2004) observation that the provision of E-learning systems by institutions and organizations does not guarantee its acceptance and usage. The implementation of E-learning systems is unlikely to achieve its objective without user's engagement. Providing enough justification for the need to conduct an assessment of potential behavioral intention patterns that are likely to impact E-learning systems usage (Selwyn, 2007). Saadé et al. (2007) concluded that students participation is critical to a successful E-learning systems implementation, hence the need to assess their behavioral attitudes. By providing the opportunity for learning and teaching to take place without much regard for time and space, E-learning has been widely adopted and accepted as a promising solution to offering learning-on-demand opportunities to individuals to reduce training time and cost. Also, it reduces the gap between needs and preference and regional, national, and international distances.

A review of E-learning system utilization literature in Ghana demonstrates a shortfall in studies investigating individual's behavioral intentions to use E-learning systems through the application of the key informant approach. Several studies (Asabere \& Mends-brew 2012b; Asabere \& Mendsbrew, 2012a; Atiso \& Adkins, 2015; Marfo \& Okine, 2010) conducted over the years, investigated the broader concept of E-learning system implementation and its related issues in Ghana's education system. Others such as (Edumadze et al., 2017; Tagoe, 2012) also presented similar studies are in this area. However, few studies focused on the evaluation of behavioral intention factors that are likely to impact on E-learning system use. Asabere \& Mends-brew (2012a) 
examined the relevance of implementing E-learning systems by ascertaining current ICT usage in education, distance learning, and E-Learning. Dadzie, (2009) focused on a relatively different approach by investigating the extent to which E-learning and E-library systems can be integrated to make the adoption of E-learning in teaching and learning attractive by examining stakeholders awareness of existing E-learning facilities, availability of enabling technology and prospects of future utilization of E-learning systems. Tagoe (2012) also investigated students' perceptions of Elearning systems use by applying the Technology Acceptance Model (TAM). Furthermore, our literature review revealed that information or data collected for most of these studies adopt the individual, dual- stakeholders or informant perspective; mostly students or teachers. Asampana et al., 2017; Asare, 2015; Asunka, 2008) examined various aspects of E-learning systems utilization by using the individual or one stakeholder approach; although, Marfo \& Okine (2010) employed a relatively broader stakeholder perspective approach, by employing students, lecturers, and university administrators in their study. This study adopts a broader stakeholder perspective approach by involving all key stakeholders in the tertiary education delivery system in Ghana to fill this gap in the literature,

This is a manifestation that not enough studies have been conducted to assert or verify the behavioral intentions of stakeholders toward the utilization of E-learning systems in the context of higher education in a Ghana. It is on this basis that this study seeks to develop an extended version of TAM to understand the potential behavioral intention patterns that are likely to support or inhibit the utilization of E-learning systems in Ghana's tertiary education institutions. The study extends the Technology Acceptance Model (TAM) by incorporating an external variable, selfefficacy. The objective of the study, therefore, is aimed at assessing the relationship that exists between antecedents of behavioral intentions, and how they impact on the usage of E-learning systems in tertiary institutions in Ghana.

\section{Literature Review and Hypothesis Development}

Malle \& Knobe (1997) observes that intention is the element that links desire and belief to action. They argued that an intentional effort that is required to fulfill the desired state influences the perception that a course of action will satisfy the desire. The technology acceptance model (TAM) in figure 1, put forward by (Bagozzi, Davis, \& Warshaw, 1992) is arguably the most comprehensively recognized innovation adoption model for assessing users acceptance or rejection of technology (Holden \& Karsh, 2010). This model has been applied in various studies examining issues of individuals' use of new technology. Consequently, researchers are in a position to predict the use of new technologies by using Davis (1989) proposal of the successive relationship of belief, attitude, intention, and behavior in TAM; while a good number of studies have used behavioral intention patterns to investigate E-learning systems adoption and usage. Perceived usefulness defined in TAM (Davis, 1989), is the degree to which a person believes that the utilization of a system will result in the enhancement of his/her job performance, while perceived ease of use is the extent to which a person conceives that utilizing a system will require less physical and mental effort.

This assertion, therefore, suggests that both perceived usefulness and perceived ease of use are indicators of attitudes that influence individuals' intention to use new technology, whiles the actual usage of the system is mediated by intentions. And perceived usefulness is also identified to be influenced directly by perceived ease of use.

Davis and Venkatesh (1996), improved TAM by suggesting that a person's intention-to-use a system is directly affected by the perceived usefulness and perceived ease of use. Intention-to-use is therefore defined as the degree to which people plan to accept technology or maximize its usage. Most studies have employed TAM to investigate the effectiveness and acceptance of E-learning system utilization (Liao \& $\mathrm{Lu}, 2008$ ). It is integrated and extended with other models and theories too. Some of these theories are Roca \& Gagne (2008), the hybrid models based on TAM and selfdetermined theory, and van Raaij \& Schepers (2008), TAM and unified theory of acceptance and usage of technology model. TAM and theory of planned behavior model is also the theory of Liaw, Huang, and Chen (2007). Even though TAM is also regarded primarily to be a very practical and 
frequently utilized, and relatively widespread and considerably parsimonious in the field of Information systems, it has also received criticisms (Hu et al., 2003). Benbasat \& Barki (2007) argued that TAM has some shortcomings such as preoccupying attention of researchers from other equally important occurrences and developments in information technology adoption research.

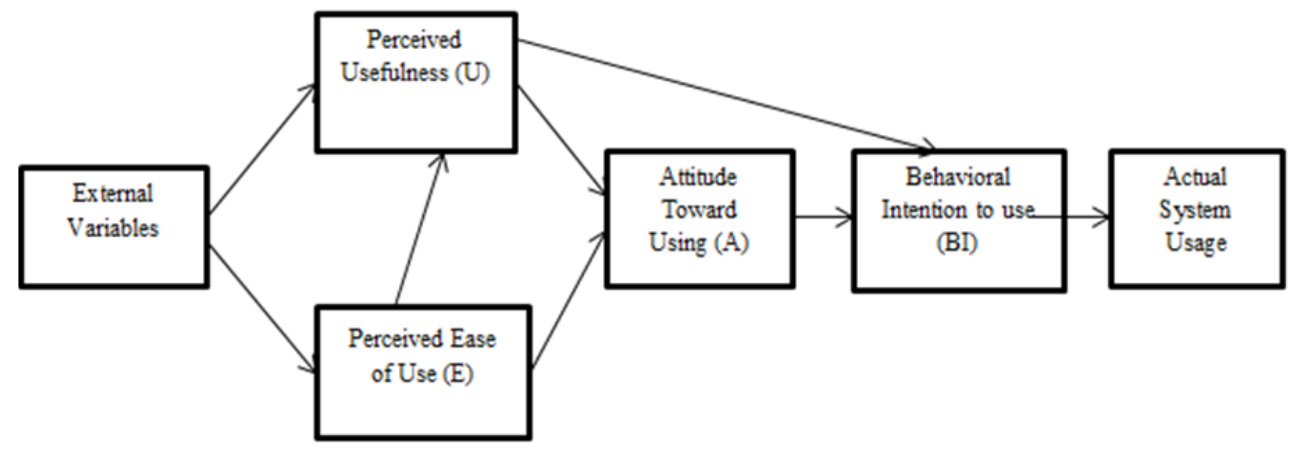

Figure 1. Technology Acceptance Model (TAM) (Davis, Bagozzi \& Warshaw, 1989, p.985).

\subsection{Behavioral Intention-to-use}

Behavioral Intention (BI) has been defined by Davis (1989) as the level to which an person has developed conscious plans to perform or not perform some specified future behavior. Behavioral intention-to-use being a mediating variable in this study depended on more on the TAM and explained as the likelihood that an individual will utilize an E-learning system when it is made available to him/her. Individual's behavioral intention-to-use plays a crucial role in the actual use of new technology (Davis, 1989). TAM suggests users' behavioral intention shapes their actual use of the technology (AU). Li et al. (2012) also discovered that perceived usefulness, perceived ease of use and self-efficacy directly, affect, system functionality; as system interactivity also impacts on users' intentions towards use E-learning systems; and perceived usefulness has a significant positive influence on users' intention to use E-learning system again, after using it for the first time.

Chang (2013) also proposed perceived value and satisfaction playing an antecedent responsibility in determining an individuals decision to use E-learning systems. Similarly, Huang et al. (2011) dealt with learning style and its influence on individuals' involvement in an online learning program; and instructors' attitudes towards technology, their teaching styles, and their control over the technology affect the learning. Although DeLone, \& McLean (2003) IS success-model made a difference between intention-to-use and system use in their updated model, which agrees that intention-to-use is at the individual construct. Similarly, Venkatesh et al. (2003) corroborated the direct relationship that exists between intention-to-use and actual use of a system. Thus, in the context of this study, intention-to-use assumed to have a positive effect on E-learning usage. Therefore, the study hypothesis that;

H1: Behavioral intention to use has the propensity to affect the Utilization of E-learning systems in Tertiary Education Institutions.

\subsection{Perceived Usefulness}

According to Pikkarainen et al., (2004), perceived usefulness (PU) is a significant antecedent of intention that inspires potential users of ICT tools to accept innovative and technologies that are easy to use. Perceived usefulness assesses the prospective users' opinion on the usefulness and effectiveness of E-learning system in improving academic and job performance (Li et al., 2012). TAM claims, TAM claims, PU directly influences behavioral intention, and users identify the usefulness of a particular technology and subsequently, formulate a positive intention of using it. In 
other words, the willingness of an individual to use a particular ICT tool for their specific activities depends on their awareness and opinions of its worth and value to their daily activities (Hanafizadeh et al. 2014). Perceived usefulness has empirically been acknowledged and proven to have a significant positive influence on usage intention; and more specifically, the utilization of Elearning systems. (Chen and Tseng, 2012). Consequently, the degree to which an individual perceives how useful an E-learning system is, the more optimistic is the intention towards its usage; hence the higher the probability of its utilization by him or her. Also, following the original Technological Acceptance Model (TAM), Yang \& Yoo (2004) assumed that perceived usefulness influences information systems (IS) usage directly. This preceded many other studies by such as (Davis, 1989; 1993) which on many occasions named perceived usefulness as the principal factor that affects information systems use, whereas perceived ease of use plays a relatively minor role; especially in the adoption process (Yang \& Yoo (2004);

H2: Perceived usefulness has the propensity to affect the Utilization of E-learning systems in higher education Institutions.

H3: Perceived usefulness will significantly affect individuals' behavioral intention-to-use Elearning systems in higher education institution

\subsection{Perceived ease of use}

Davis (1989), defined perceived ease of use (PEOU) as the degree to which a user considers the use of a specific technology will be free from effort. In the context of E-learning, perceived ease of use relates to the individual user's perception of easiness of using the system associated with the accomplishment of the E-learning responsibility. TAM claims that perceived usefulness will be influenced by perceived ease of use when users' find technology easy to use, their perception is that the technology is very beneficial. TAM provides the causal connection between these two fundamental constructs, that is, Perceived Ease of Use and Perceived Usefulness as the two essential determinants. Similarly, (Venkatesh, 2000) projects that perceived ease of use will soon be the dominant indicator of adoption of new technology-based applications. Its influence on individuals' intentions to use E-learning has been thoroughly proven by studies (Chen and Tseng, 2012). As a result, the more a prospective user perceives that the adoption of E-learning systems in his/her academic activities will demand less physical and mental effort, the more positive or likelihood intention towards its usage; so higher the possibility that it will be utilized (Mohammadi (2015). Moreover, perceived ease of use is accepted to indirectly influence intention-to-use through perceived usefulness in E-learning adoption context as well (Chen and Tseng, 2012).

H4: Perceived ease of use will significantly affect individuals' behavioral intention-to-use Elearning systems in higher educational institutions.

H5: Perceived ease of use positively affects perceived usefulness of E-learning systems in Higher education institutions

\subsection{Self-Efficacy}

Bandura (1977), propounded the social cognition theory that has developed to become is one of the key predictors in investigating the enthusiasm of learning. In this study, we argue that individuals may tend to avoid a challenging task if they find that the execution of that job surpasses their ability and skills. He indicated that perceived self-efficacy plays a vital role in influencing motivation and behavior and that an individual is expected to act in a way that person thinks will yield excellent results than the perceived ones with a disapproving or unacceptable outcome or consequence. Therefore, these same individuals are more likely to volitionally participate in a task if they find themselves capable of performing the function.

In a related study, Kinzie et al. (1994) explained that self-efficacy is a person's self-assurance in the person's capability to influence his or her performance on tasks. It is a manifestation of an individual's ability to perform or undertake specific conduct which is expected to produce a specific outcome. Self-efficacy, being central to the cognition theory is centered on the trust in an individuals' efficiency and efficacy in performing a particular project or task. Also (Pituch \& Lee, 
2006) defined self-efficacy in the context of E-learning adoption as the confidence in an individual's capability to achieve a targeted learning skills by the use of an E-learning system,"

Contemporarily, researchers examining the individual's E-learning adoption behavior are frequently utilizing individuals' self-efficacy variable. Ong \& Lai (2006) acknowledged that selfefficacy influenced both the intention to participate in E-learning, followed by performance. While Lim's (2000), named self-efficacy as a major factor that influences users' satisfaction with Elearning systems. This paper, based on the above literature hypothesis that;

H6: User's Self-Efficacy will significantly affect an individual's behavioral intention-to-use Elearning systems in Tertiary Education Institutions

\section{Research Methodology}

A survey methodology approach was used to collect data used for testing the research model of the study. This methodology was adopted based on Kerlinger's (1973) assertion of its appropriateness for obtaining personal beliefs and the capacity to improve the generalizability of results. Furthermore, the choice a survey method is due to its suitability for studies that have individual people as the unit of analysis, and its underlying strength relative to other research methods regarding its ability to measure a wide variety of unobservable data such as attitudes, beliefs, behaviors and factual information.

\subsection{Development of Instruments}

A structured survey questionnaire instrument made up of two sections ( $A$ \& $B$ ) was developed to capture responses from respondents. Part $A$ was used to capture the demographic characteristics of the respondents, while section B was developed to measure constructs in the proposed research model by adapting previous items that have demonstrated significant validity in technology adoption and more specifically, in E-learning systems adoption context. Five items were adapted from Delone \& Mclean (2003) to evaluate perceived usefulness; while four items used in assessing perceived ease of use were adapted from Wang \& Liao (2008), and Tarhini et al., (2016). Intentionto-use had four items employed for its measurement, and these were adapted from Venkatesh (2000), and Lin, 2011. Self-Efficacy was measured using four items adapted from Tan \& Teo (2000). And three items measuring E-learning adoption feasibility were adapted from Delone \& Maclean (2003).

\subsection{Sample and Data Collection}

Aparicio et al., (2016), identified ten stakeholders in E-learning system application, namely; students, employers, educational institutions, accreditation bodies, teachers, content providers, education ministry, and teachers' association students' commission and technology providers, by of their direct and indirect interactions. This research sought to collect data from five key stakeholders of the E-learning system using the key informant approach. These were school governing board members, school management members, faculty members, schools' ICT staff and students from five tertiary education institutions. Because all items were adopted from previous studies while ensuring the adequate reliability of the research instruments, we pre-tested the instruments to fit the context of this study. The questionnaire was tested by five students, three faculty members, three management members and one governing council member in one of the technical universities in Ghana. Subsequently, the questionnaire was reviewed, and a final version was considered in consonant with comments and feedback from the pilot-text, using a seven-point Likert scale.

The questionnaire which was self-administered were used to elicit responses from the respondents which included; members of governing councils, school management members, faculty members, ICT department staff and students involved teaching staff and students from five tertiary institutions in Ghana. These institutions were made up of two public tertiary institutions, two private tertiary institutions, and one government technical university. The items anchored on a 7point Likert scale (1=strongly disagree to $7=$ strongly agree. Out of the 319 distributed 
questionnaires, a total of 282 were retrieved, resulting in an $88.4 \%$ response rate. After screening the questionnaire, ten voids ones were taken out due to unattended items on them by the respondents which can affect the outcome of the results. Therefore, 272 utilized questionnaires were involved in analyzing the data for the study.

\section{Analysis and Results}

\subsection{Demographic and Descriptive Statistics}

Majority of the respondents of this study were found to be men $(55.9 \%)$ and the rest $(44.1 \%)$ being female. The highest percentage (43.4\%) fell within the age range of 18 and 25 years old; followed by those who were 40 or more years old, 31 and 39 years old, 26 and 30 years old, less than 18 old with $29.8 \%, 18.0 \%, 8.5 \%$ and $0.4 \%$ respectively. With regards to the affiliated tertiary institution category of the respondents, $37.5 \%$ were from public tertiary institutions, $35.7 \%$ from technical universities and the remaining $26.8 \%$ from private universities. Also, the status of the respondents; governing council members $(1 \%)$, management members $(7.7 \%)$, faculty members $(32.0 \%)$, ICT staff $(8.1 \%)$ and students $(51.1 \%)$. An inquiry about the number of years of E-learning experience revealed that $(45.2 \%)$ had no experience. $(6.6 \%)$ had one years' experience, $(24.3 \%)$ with two years' experience, $(13.2 \%)$ had three years' experience, and $(10.7 \%)$ having more than four years of E-learning experience. $42.5 \%$ had also participated in an internet programme before while the remaining $54.8 \%$ had never been involved or engaged in an internet-based application. With regards to their daily utilization of internet, $0.4 \%$ of the respondents reported that they never use the internet, $4.0 \%$ seldom uses the internet, $21.3 \%$ sometimes uses the internet, $41.2 \%$ usually utilizes the internet and the rest of $31.1 \%$ always uses the internet. In conclusion, $3.7 \%$ were a novice, 58.5 were intermediary, and $37.9 \%$ as experts respectively as far as their computer literacy was concerned.

\subsection{Data Analysis}

The primary objective of this study is to determine antecedence of behavioral intention, and their impact on E-learning systems utilization in Ghana's tertiary education institutions. The model was tested using the partial least square, structural equation modeling (PLS-SEM) technique to validate the research variables, their relationships, and the impact they give to each other. PLS-SEM is a second-generation multivariate technique capable of processing latent variable models, and also appropriate when the objectives of the study are focused on predicting the relationships between variables, and also testing or predict the theoretical model that has been conceptualized based on literature (Sosik et al., 2009; Chin, 1998) Proceeding, the measurement model was first examined to check reliability and validity of the measures of constructs, followed by an analysis of the structural model to obtain the path coefficient between the constructs.

\section{Results and Analysis of PLS-SEM}

According to Hair et al. (2016), PLS-SEM model estimation provides empirical measures of the relationships between the indicators and the constructs (measurement model), likewise between the constructs (structural model). A PLS model comprises two elements. Firstly, the structural model that constitutes the constructs, and also exhibits the relationship existing between them. The second component is the measurement models of the construct that shows the relationship between the constructs and the indicator variables. The PLS was chosen based on the assertion by Chin (1998) that it offers a higher level of flexibility in testing theoretical data while relying on prediction oriented measures that are non-parametric. The study utilized SmartPLS3.0 software (Ringle et al., 2015) for the analysis. 


\subsection{Evaluation of the Measurement Model}

We examined the reliability, convergent, and the discriminant validity of the measurement model to established valid results. Composite reliability was applied to test reliability. As it's shown in table 1, all composite reliability values exceeded the recommended values of 0.7 , hence confirming internal consistency reliability. Average variance extracted (AVE) was used to test for convergent validity. In Table 1, all average variance extracted from the latent variables were more than the acceptable value of 0.5 satisfying Fornell \& Larcker (1981) condition of establishing convergent validity. Table 2 , is utilized for assessing discriminant validity by demonstrating that the square root of the average variance extracted for each latent construct exceeds the correlation it has with other constructs, providing enough evidence to support discriminant validity (Fornell \& Larcker, 1981). The results of the measurement model demonstrate the reliability of all the items and also convergent validity. This is an indication that the latent variables of the research model are appropriately represented by all the questions posed to the respondents.

Table 1: Mean, Standard Deviation and Convergent Validity Analysis $(\mathrm{N}=237)$

\begin{tabular}{|c|c|c|c|c|c|c|}
\hline Constructs & Indicators & Mean & $\begin{array}{l}\text { Standard } \\
\text { Deviation }\end{array}$ & $\begin{array}{l}\text { Standardized } \\
\text { Loadings }\end{array}$ & $\begin{array}{l}\text { Composite } \\
\text { Reliability }\end{array}$ & AVE \\
\hline Perceived & PU1 & 5.173 & 1.684 & 0.855 & 0.846 & 0.536 \\
\hline \multirow[t]{4}{*}{ Usefulness } & PU2 & 5.735 & 0.975 & 0.503 & & \\
\hline & PU3 & 5.705 & 0.992 & 0.544 & & \\
\hline & PU4 & 5.776 & 0.943 & 0.876 & & \\
\hline & PU5 & 5.051 & 1.574 & 0.795 & & \\
\hline Perceived & PEUO1 & 5.143 & 1.558 & 0.812 & 0.839 & 0.567 \\
\hline \multirow[t]{3}{*}{ Ease of use } & PEOU2 & 3.898 & 2.136 & 0.740 & & \\
\hline & PEOU3 & 4.643 & 2.062 & 0.808 & & \\
\hline & PEOU4 & 4.908 & 1.591 & 0.640 & & \\
\hline Self- & SE1 & 5.851 & 1.069 & 0.791 & 0.909 & 0.715 \\
\hline \multirow[t]{3}{*}{ Efficacy } & $\mathrm{SE} 2$ & 6.449 & 0.744 & 0.757 & & \\
\hline & SE3 & 5.173 & 1.578 & 0.920 & & \\
\hline & $\mathrm{SE} 4$ & 3.898 & 2.131 & 0.896 & & \\
\hline Behavioral & BIU1 & 5.931 & 1.029 & 0.685 & 0.860 & 0.608 \\
\hline Intention to & BIU2 & 5.816 & 0.962 & 0.880 & & \\
\hline \multirow[t]{2}{*}{ Use } & BIU3 & 5.276 & 1.701 & 0.812 & & \\
\hline & BIU4 & 6.143 & 1.069 & 0.728 & & \\
\hline E-leaming & ELAF1 & 4.643 & 2.086 & 0.832 & 0.825 & 0.614 \\
\hline Systems ELAF2 & 5.061 & 1.640 & 0.829 & & & \\
\hline Usage & ELAF3 & 5.929 & 1.052 & 0.677 & & \\
\hline
\end{tabular}

Table 2: Fornell-Lacker Criterion for Discriminant Validity

\begin{tabular}{|l|c|c|c|c|c|}
\hline & $\begin{array}{c}\text { Behavioral } \\
\text { Intention-to-use }\end{array}$ & $\begin{array}{c}\text { E-learning } \\
\text { Systems Usage }\end{array}$ & $\begin{array}{c}\text { Perceived } \\
\text { Ease of use }\end{array}$ & $\begin{array}{c}\text { Perceived } \\
\text { Usefulness }\end{array}$ & $\begin{array}{c}\text { Self- } \\
\text { Efficacy }\end{array}$ \\
\hline $\begin{array}{l}\text { Behavioral } \\
\text { Intention-to-use }\end{array}$ & $\mathbf{0 . 7 8 0}$ & & & & \\
\hline $\begin{array}{l}\text { E-learning } \\
\text { Systems Usage }\end{array}$ & 0.633 & $\mathbf{0 . 7 8 3}$ & & & \\
\hline $\begin{array}{l}\text { Perceived Ease } \\
\text { of use }\end{array}$ & 0.591 & 0.667 & $\mathbf{0 . 7 5 3}$ & & \\
\hline $\begin{array}{l}\text { Perceived } \\
\text { Usefulness }\end{array}$ & 0.611 & 0.536 & 0.550 & $\mathbf{0 . 7 3 2}$ & \\
\hline Self-Efficacy & 0.504 & 0.621 & 0.652 & 0.562 & $\mathbf{0 . 8 4 5}$ \\
\hline
\end{tabular}




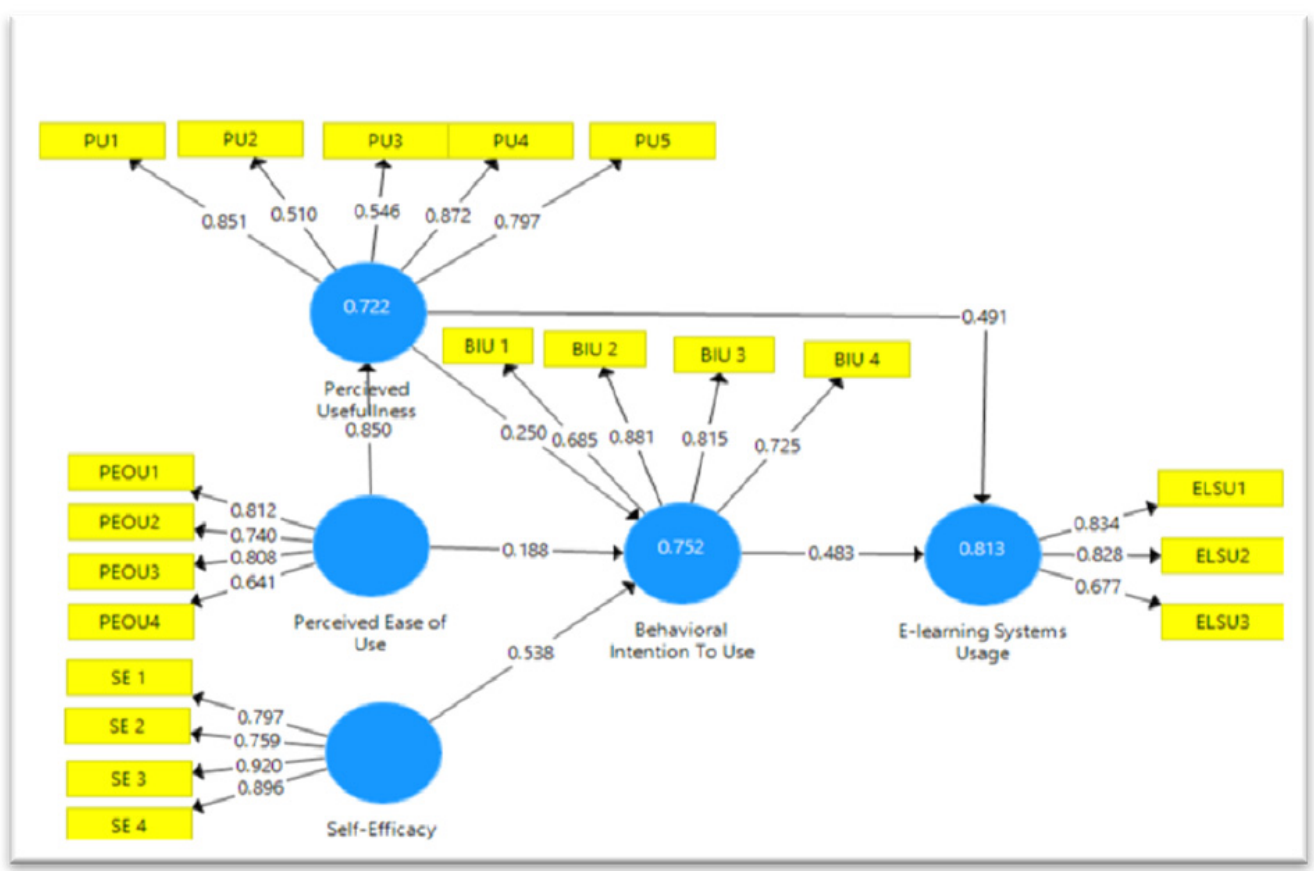

Figure 4: Path Estimation Results

\subsection{Assessment of the Structural Model}

Once there is a confirmation that the constructs measures are reliable and valid, the next step of the analysis is the examination of the structural model results. Before this stage, the test was done on all the constructs for multicollinearity and to confirm significant levels of collinearity between sets of predictor variables by calculating the variance inflation factor (VIF). Hair et al.., (2011) insisted that in the context of PLS-SEM, a tolerance VIF value fall within 0.20 and 5; and that, multicollinearity may pose a problem if VIF exceeds 5 or lower than 0.20 . The result demonstrates the non-existence of multicollinearity, with VIF values ranging between 1.3 and 4.4. Urbach \& Ahlemann (2010) proposed that the first essential criterion for assessing PLS structural equation model endogenous latent variable (LV) is the analysis of the coefficient of determination $\left(R^{2}\right)$. The result of the structural model testing is presented in Table 4 and a graphical presentation shown in Figure 4. Table 3 shows the values of the coefficient of determination $R^{2}$ for each endogenous variable. Table 4 depicts the $R^{2}$ for each endogenous variable. Perceived usefulness (PU) had a $R^{2}$ value of $0.722(72.2 \%)$, and behavioral intention-to-use, had a $R^{2}$ value of $0.752(75.2 \%)$. On the other hand; the endogenous variable of the research model, E-learning systems usage (ELSU) attained a $R^{2}$ value of $=0.813$. The implication is that the proposed model explains $81.3 \%$ variance of the utilization of E-learning systems in Ghanaian tertiary institutions.

All six hypotheses were supported as well, $\mathrm{H} 1$ posits that behavioral. Intention-to-use positively impacts on the utilization of E-learning systems. As presented in shown figure 4, path coefficient is $0.483(p<0.000)$, thus supporting $\mathrm{H} 1$. $\mathrm{H} 2$ proposed that perceived usefulness impacts on E-learning systems usage. This was supported (path coefficient $=0.491, p<0.000$ ). Thirdly, H3 states that perceived usefulness influences individuals' behavioral intention-to-use, this is supported as well (path coefficient $0.250, \mathrm{p}<0.000$ ). $\mathrm{H} 4$ postulates that perceived ease of use positively impacts E-learning systems usage (path coefficient $=0.188, p<0.000$ ), is confirmed. Furthermore, $\mathrm{H} 5$ asserted that perceived usefulness would influence E-learning systems usage positively. Thus, (path coefficient $=0.850, \mathrm{p}<0.000$ ) is also supported. Finally, $\mathrm{H} 6$ postulated that 
self-efficacy has a positive relationship with behavioral intention-to-use (path coefficient $=0.538$, $\mathrm{p}<0.000)$, and this is also confirmed

Table 3: Results of Path Modeling

\begin{tabular}{llcccc}
\hline Hypothesis & Relationship & Path coefficient & T-statistics & P-Value & Decision \\
& & & & \\
\hline H1 & BUI $\rightarrow$ ELSU & 0.483 & 6.063 & 0.000 & Supported \\
H2 & PU $\rightarrow$ ELSU & 0.491 & 6.000 & 0.000 & Supported \\
H3 & PU $\rightarrow$ BIU & 0.250 & 2.269 & 0.024 & Supported \\
H4 & PEOU $\rightarrow$ BIU & 0.188 & 1.718 & 0.086 & Supported \\
H5 & PEOU $\rightarrow$ PU & 0.850 & 31.470 & 0.000 & Supported \\
H6 & SE $\rightarrow$ BIU & 0.538 & 6.013 & 0.000 & Supported \\
\hline
\end{tabular}

\subsection{Mediator Analysis of Behavioral Intention-to-use (BIU)}

Mediation analysis is an essential subject matter in the context of PLS-SEM. As depicted in the general mediation model in figure 6 , mediation draws attention to theoretically established direct path relationship between two constructs $X_{1}$ and $X_{3}$, as well as an additional theoretically relevant component $X_{2}$, which indirectly provides information on the immediate effect through its indirect effect. Therefore, the indirect relationship through the $X_{2}$ (mediator) affects the direct relationship from $X_{1}$ (independent variable) to $X_{3}$ (dependent variable). In the context of this study, the constructs perceived usefulness, perceived ease of use and self-efficacy are the independent variables $\left(\mathrm{X}_{1}\right)$. E-learning systems usage is the dependent variable $\left(\mathrm{X}_{3}\right)$, while the behavioral intention is the mediator $\left(X_{2}\right)$. Behavioral intention-to-use is assumed to mediate or indirectly provides information on the direct effect from perceived usefulness to E-learning systems usage, perceived ease of use to E-learning systems usage and self-efficacy to E-learning systems usage. Baron \& Kenny (1986) proposed that the following conditions must be fulfilled for a or variable to function as a mediator. In other words, the mediator account variations suggestively for the variations in the dependent variable, once the paths p12 and p23 are well organized. An earlier significant relationship involving the two variables; the independent and dependent variables changes its value significantly.

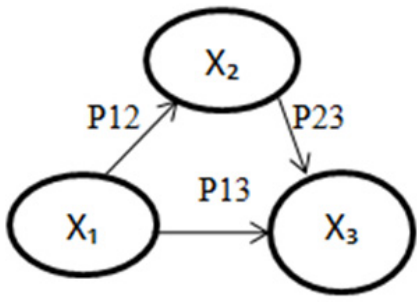

Source: Hair et al., 2013

We applied Preacher \& Hayes $(2004,2008)$ technique of testing mediation effects, while adopting Hair et al., (2013) mediator analysis procedure in PLS-SEM. The mediator effect BIU on the relationship between perceived usefulness and E-learning systems usage; perceived ease of use and E-learning systems usage; and then self-efficacy and E-learning systems usage in the research model.

Table 4: coefficients without the mediator

\begin{tabular}{|c|c|c|}
\hline & Path Coefficient & P Value \\
\hline $\mathrm{PU} \rightarrow \mathrm{ELSU}$ & 0.860 & 0.000 \\
\hline $\mathrm{PEOU} \rightarrow \mathrm{ELSU}$ & 0.566 & 0.000 \\
\hline $\mathrm{SE} \rightarrow \mathrm{ELSU}$ & 0.706 & 0.000 \\
\hline
\end{tabular}


An analysis of the mediator effect BIU in the structural model was done without the potential mediating variable. Results from bootstrapping procedure as shown in Table 5 indicates that the respective path coefficients were significant. Hence the study focuses on the mediator analysis of the relationships between; PU and ELSU, PEOU and ELU, SE and ELSU. Further analysis of the indirect effect conducted by adding the mediator variable (BIU) to determine whether the indirect effects of; PU on ELU, PEOU on ELSU, SE on ELSU via mediator variable (BIU) are significant. As depicted in figure $5 a, 5 b$, and $5 c$; the indirect effect size (P12 $\times$ P23) of all the relationships estimated where significant. That is; $(\mathrm{PU} \rightarrow \mathrm{BIU}) \times(\mathrm{BIU} \rightarrow \mathrm{ELSU})=0.354,(\mathrm{PEOU} \rightarrow \mathrm{BIU}) \times$ $(\mathrm{BUI} \rightarrow \mathrm{ELSU})=0.313,(\mathrm{SE} \rightarrow \mathrm{BIU}) \times(\mathrm{BIU} \rightarrow \mathrm{ELSU})=0.817$.

A prove of the significance of all the indirect effects was required to enable us to conclude that BIU indeed mediates the relationships between; PU and ELSU, PEOU and ELSU, SE and ELSU. Finally, we examined the strengths of these mediators by using the variance accounted for (VAF) to assist us to answer the question; "how much the mediator variable absorbs." By applying the assessment VAF formula by Hair et al. (2013) shown in figure 7, the strengths (VAF value) of the mediation effect of BIU on the relationships between; PU and ELSU, PEOU and ELSU, SE and ELSU were $0.42,0.67$ and 1.11 respectively. This is implicative of the fact that BIU plays a partial mediating role in the relationship between perceived usefulness and E-learning adoption feasibility. Likewise, BIU plays a mediating role in the relationship between perceived ease of use and Elearning systems usage. However, in the case of the relationship between self-efficacy and Elearning systems usage, BIU plays a full mediation role.

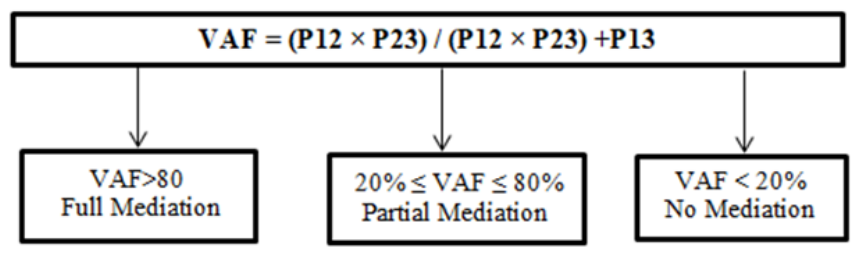

Figure 7: Assessment of Variance Accounted For (VAF) Source Hair et al. 2013
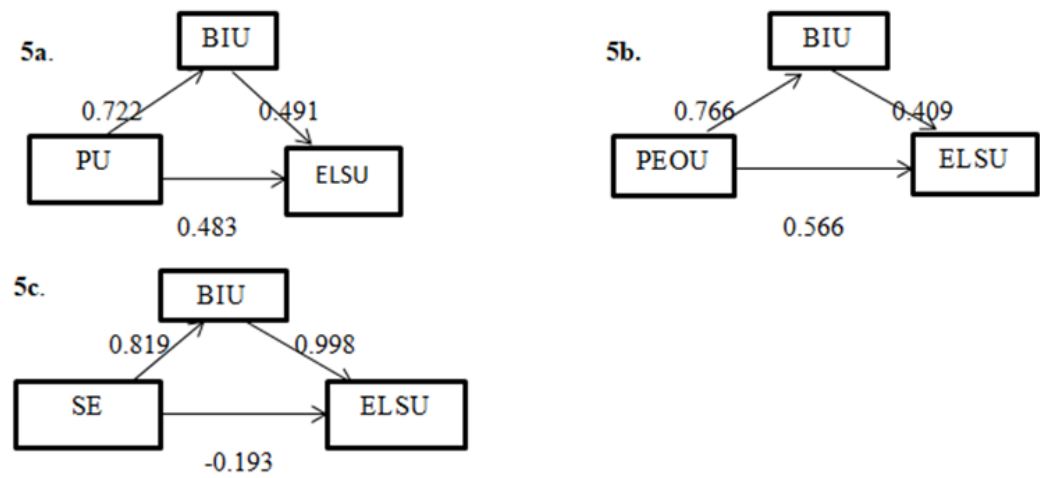

Figure 5. Path Diagrams of Mediation Effects of Behavioral intention-to-use (BIU)

\section{Discussion and Conclusion}

\subsection{Discussion}

The study developed an extended TAM by incorporating E-learning self-efficacy variable; we also went further by analyzing the mediating role of individuals' behavioral intention-to-use on E-learning systems usage. All TAM related hypotheses $(3,4 \& 5)$ were proven to have positive correlations 
that are statistically significant. This is consistent with prior studies such as (Park, 2009; Lee et al..2005; Asiri et al.., 2012), affirming TAM as a useful theoretical model to understand and explicate behavioral intention to utilize E-learning systems. Similarly, Hanazadeh et al. (2014) belief that the preparedness of an individual to utilize ICT tool for any purpose is dependent or influenced by their consciousness of the worth of such a tool.

However, it is also imperative to recognize that the significant relationships were evident in hypothesis 4 and 3 . This indicates that, at least, in the context of Ghana's tertiary education system, stakeholder's behavioral intention-to-use E-learning system is influenced fundamentally by perceived usefulness and individual's self-efficacy, instead of perceived ease of use. This is in accordance with Venkatesh, et al. (2003) who did not find any significant pre-implementation effect of perceived ease of use on E-learning utilization, and also by Bhattacherjee \& Premkumar (2004) who submitted that, considering the fact that user belief and attitudes are vital in determining information ICT usage, there may be change in perceptions with time as users gain initial experience with IT usage such as E-learning systems; in which subsequent usage may change their perception. This study holds the view that perceived ease of use will only have a postimplementation influence on E-learning systems usage where it is anticipated that users may have gained enough experience in the systems' usage. Thus agreeing with Adam et al., (1992) that as users become familiar with novel ICT system, perceived ease of use becomes profound since issues of instrumentality grow significantly over concerns about the ease of using it. Another revealing finding of this study is the important role of E-learning self-efficacy in influencing behavioral intention to use E-learning. This is an agreement with Park (2009) suggestion that Elearning self-efficacy may be seen as an intrinsic motivational factor that could assist individuals self-regulate their motivation; supporting Bandura (1994) assertion that self- efficacy brings about a more active learning process. In summary, the results reveal that perceived usefulness, perceived ease of use and self-efficacy will positively influence the utilization of E-learning systems in higher education institutions through the mediating role of individuals' behavioral intention-to-use.

\subsection{Conclusion}

The study provides significant contributions to the research of E-learning systems usage by tertiary education in developing countries. The study established an extended TAM by incorporating an external variable; self-efficacy observed to be an influential factor in enhancing e-learning system utilization in Ghana's tertiary education context. The findings of the study were found to be consistent and in harmony with numerous prior TAM studies, which identified both perceived usefulness and perceived ease of use are crucial determinants for technology utilization (Davis, 1989; Lee, 2006; Ong \& Lai, 2006). We established that self-efficacy had the most predictive power in comparison with perceived usefulness and perceived ease of use with regards to behavioral intention-to-use. This result implies that self-efficacy is the primary behavioral intention factor in determining E-learning system utilization, in Ghana's tertiary education context. Perceived ease of use also exhibited a significant indirect effect on E-learning systems utilization through perceived usefulness; this is an indication that stakeholders tend to utilize E-learning systems if they understand them to be easy to use. According to the results, $81.3 \%$ of behavioral intention to use E-learning systems has been explained by the proposed research model. This study also responded to other researchers such as (Legris et al., 2003; Wu \& Wu, 2005), who have been critical of TAM, through their advocacy that it is appropriate to incorporate other external and internal variables to provide a broad scope of ICTs adoption behavioral study. Also, studies such as (Csikszentmihalyi, 1993; Cheng, 2011) who requested for the need for TAM to integrate factors related to human change processes to provide more accurate explanations by delivering a useful external variable of individual characteristics of the TAM model to further the research.

Earlier studies on E-learning systems utilization in tertiary education in developing countries have concentrated on characteristics of users, example, programme context, learning context, the perception of teaching and learning quality, and the broad approach to teaching and learning. In this study, we proved that individuals self-efficacy about computers, internet, and usage of ICT tools are related to the utilization of E-learning systems in higher education. It also makes a significant 
contribution by conceptualizing individual characteristics is a critical c factor between individuals perception of technology adoption and their behavioral intentions to utilize E-learning systems.

The findings are further demonstrations that the TAM constructs have both direct and indirect effect on stakeholders of higher education behavioral intention to utilize E-learning systems, therefore, the potential for practical application in the development and management of E-learning system implementation by higher education providers. Based on our findings, we recommend that in addition to acquiring the necessary knowledge and skills, methods and strategies are needed to develop by higher education, providers in developing countries to increase the level of individual's self-efficacy to serve as a motivation to utilize E-learning systems. Also, utilizing both online and offline support, and the introduction of E-learning manuals can be used to boast E-learning selfefficacy. This particular research contributes to E-learning literature with specific focus to the development of a model that is intended to enhance our understanding and appreciation of potential behavioral intention factors that are likely to underpin the successful utilization of Elearning systems for higher education delivery. Similarly, the mediating role of behavioral intentionto-use and the introduction of self-efficacy, coupled with its significant impact on the establishment of E-learning systems usage.

\section{Reference}

Adams, D. A., Nelson, R. R., \& Todd, P. A. (1992). Perceived usefulness, ease of use, and usage of information technology. MIS Quarterly, 16, 227-248.

Alsabswy, A. Y., Cater-Steel, A., \& Soar, J. (2013). I.T infrastructure services as a requirement for e-learning system success. Computers \& Education, 69, 431-451.

Aparicio, M., Bacao, F., \& Oliveira, T. (2016). Cultural impacts on e-learning systems' success. The Internet and Higher Education, 31, 58-70.

Asabere, N. Y., \& Enguah, S. E. (2012). Use of Information \& Communication Technology (ICT) in Tertiary Education in Ghana: A Case Study of Electronic Learning (E-learning). International Journal of Information and Communication Technology Research, 2(1), 62-68.

Asabere, N. Y., \& Mends-brew, E. (2012). Distance Learning and Electronic Learning (E-Learning): Are They the Same? An Overview of Some Tertiary Institutions in Ghana 1.

Asampana, I., Akanferi, A. A., \& Ami-Narh, J. (2017). Reasons for poor acceptance of web-based learning using an LMS and VLE in Ghana. Interdisciplinary Journal of Information, Knowledge \& Management, 12.

Asiri M., S., , Mahmud R, K. Abu-Bakar, and A. F. Ayub, "Factors influencing the use of learning management system in Saudi Arabian Higher Education: A theoretical framework," Higher Education Studies, vol. 2, p. p125, 2012

Asunka, S. (2008). Online learning in higher education in Sub-Saharan Africa: Ghanaian University students' experiences and perceptions. The International Review of Research in Open and Distributed Learning, $9(3)$.

Atiso, K., \& Adkins, D. (2015). Librarians, Research scientists and ICT adoption in research institutes in Ghana.

Bagozzi, R. P., Davis, F. D., \& Warshaw, P. R. (1992). Development and test of a theory of technological learning and usage. Human Relations, 45(7), 660-686.

Bala, H. and Venkatesh, V. (2013), "Changes in employees' job characteristics during an enterprise system implementation: a latent growth modeling perspective", MIS Quarterly, Vol. 37 No. 4, pp. 1113-1140.

Bandura, A. (1977). Self-efficacy: toward a unifying theory of behavioral change. Psychological Review, 84, 191-215.

Baron, R. M., \& Kenny, D. A. (1986). The moderator-mediator variable distinction in social psychological research: Conceptual, strategic and statistical considerations. Journal of Personality and Social Psychology, 51, 1173-1182.

Benbasat, I., and Barki, H. (2007). Quo Vadis, TAM? Journal of the AIS, 8:4.

Bhattacharjee, A., "Social Science Research: Principles, Methods, and Practices" (2012). USF Tampa Bay Open Access Textbooks Collection. Book 3. http://scholarcommons.usf.edu/oa textbooks/3

Bidin, S., \& Ziden, A. A. (2013). Adoption and application of mobile learning in the education industry. ProcediaSocial and Behavioral Science, 90, 720-729.

Bloch, M., Blumberg, S. and Laartz, J. (2012), "Delivering large-scale IT projects on time, on the budget, and on value," McKinsey \& Company, October, pp. 1-6.

Bondarouk, T., \& Ruël, H. (2010). Dynamics of e-learning: theoretical and practical perspectives. International journal of training and development, 14(3), 149-154. 
Borstorff, P. C., and Keith, L. S. 2007. Student perceptions and opinions towards e-Learning in the college environment. Academy of Educational Leadership Journal, 2007, 11(2): ISSN 1095-6328.

Byrne, B. M. (2001). Structural equation modeling with AMOS: Basic concepts, applications, and programming. Mahwah, NJ: Lawrence Erlbaum.

Chang, C. C. (2013). Exploring the determinants of e-learning systems continuance intention in academic libraries. Library Management, 34(1/2), 40-55.

Chau, P. Y. (1996). An empirical assessment of a modified technology acceptance model. Journal of management information systems, 13(2), 185-204.

Chen, H. R., \& Tseng, H. F. (2012). Factors that influence acceptance of web-based e-learning system for the in-service education of junior high school teachers in Taiwan. Evaluation and Program Planning, 35, 398406.

Cheng, Y. M. (2011). Antecedents and consequences of e-learning acceptance.Information Systems Journal, 21(3), 269-299.

Chin, W. W. (1998). The partial least squares approach for structural equation modeling. in G. A. Marcoulides (Ed.), Modern methods for business research (pp. 295-236). London: Lawrence Erlbaum Associates.

Chin, W. W. (2010). How to write up and report PLS analyses. In Handbook of partial least squares (pp. 655690). Springer Berlin Heidelberg.

Chiu, C. M., Hsu, M. H., Sun, S. Y., Lin, T. C., \& Sun, P. C. (2005). Usability, quality, value and e-learning continuance decisions. Computers \& Education, 45, 399-416.

Csikszentmihalyi, M. (1993). The evolving self: A psychology for the third millennium. New York: Harper Collins.

Davis, F. D. (1989). Perceived usefulness, perceived ease of use, and user acceptance of information technology. MIS Quarterly, 319-340.

Davis, F. D., Bagozzi, R. P., \& Warshaw, P. R. (1989). User acceptance of computer technology: a comparison of two theoretical models. Management Science, 35(8), 982-1003.

DeLone, W. H., \& McLean, E. R. (2003). The DeLone and McLean model of information systems success: A ten-year update. Journal of Management Information Systems, 19(4), 9-30.

Dominici, Gandolfo, and Federica Palumbo. "How to build an e-learning product: Factors for student/customer satisfaction." Business Horizons 56, no. 1 (2013): 87-96.

Edumadze, J. K., Ogoe, J. I., Essilfie, G., Edumadze, G. E., \& Graham, R. E. (2017). E-learning at the university of Cape Coast, Ghana-are our distance education students technologically ready? The Online Journal of Distance Education and e-Learning, 5(1), 47

Fornell, C. G., \& Larcker, D. F. (1981). Evaluating structural equation models with unobservable variables and measurement error. Journal of Marketing Research, 18(1), 39-50

Gefen, D., \& Straub, D.W. (2000). The relative importance of perceived ease of use in IS adoption: a study of ecommerce adoption. Journal of the Association for Information Systems, 1(1), 1-28.

Goatham, R. (2009), "The story behind the high failure rates in the IT sector," Calleam consulting, available at http://calleam.com/WTPF/wp-content/uploads/articles/Whatmakes.pdf

Goldberger, A. S., \& Duncan, O. D. (1973). Structural equation models in the social sciences. New York: Seminar Press.

Hair Jr, J. F., Hult, G. T. M., Ringle, C., \& Sarstedt, M. (2016). A primer on partial least squares structural equation modeling (PLS-SEM). Sage Publications.

Hair, J. F., Ringle, C. M., \& Sarstedt, M. (2011). PLS-SEM: Indeed a silver bullet. Journal of Marketing Theory and Practice, 19(2), 139-151.

Hair, J.F., Hut, G.T. M., Ringle C.M., Sarstedt. M., 2013. A Primer on Partial Least Squares Structural Equation Modeling (PLS-SEM). Sage, Thousand Oaks

Hanafizadeh, P., Behboudi, M., Khoshksaray, A., \& Shirkhani Tabar, M. (2014). Mobile-banking adoption by Iranian bank clients. Telematics and Informatics, 31(1), 62-78.

Henseler, J., Ringle, C. M., \& Sinkovics, R. R. (2009). The use of partial least squares path modeling in international marketing (SSRN scholarly paper no. ID 2176454. Rochester, NY: Social Science Research Network (Retrieved from) http://papers.ssrn.com/ abstract=2176454

Henseler, Jörg; Ringle, Christian M.; \& Sarstedt, Marko (2012). Using partial least squares path modeling in international advertising research: Basic concepts and recent issues. Pp. 252-276 in Okzaki, S., ed. Handbook of partial least squares: Concepts, methods, and applications in marketing and related fields. Berlin: Springer.

Ho, C. L., \& Dzeng, R. J. (2010). Construction safety training via e-learning: Learning effectiveness and user satisfaction. Computers \& Education, 55, 858-867.

Hock, C., Ringle, C.M., Sarstedt, M: Management of multi-purpose stadiums: importance and performance measurement of service interfaces. Int. J. Serv. Technol. Manag. 14(2), 188-207 (2010)

Holden, R. J., \& Karsh, B. T. (2010). The technology acceptance model: its past and its future in health care. Journal of Biomedical Informatics, 43, 159-172

Hoyle, R. H. (1995). The structural equation modeling approach: basic concepts and fundamental 
Hu, P., Hu, P. J., Clark, T. H. \& Ma, W. (2003). Examining technology acceptance by school teachers: a longitudinal study. Information and Management, 41, 227-241.

Huang, E.Y., Lin, S.W. and Huang, T.K. (2011), "What type of learning style leads to online participation in the mixed-mode e-learning environment? A study of software usage instruction", Computers \& Education, Vol. 58 No. 1 , pp. 338-49.

In R.H. Hoyle (ed.), Structural equation modeling: concepts, issues, and applications (pp. 1-15). Thousand Oaks, CA: Sage Publications.

Jenkins, M. \& Hanson, J. (2003). E-learning series: A guide for senior managers, Learning and Teaching Support Network (LSTN) Generic Centre, United Kingdom

Kerlinger, F.N. (1973), Foundations of Behavioral Research, 2nd ed., Holt, Rinehart and Winston, New York, NY.

Kim, H.W. (2011), "The effect of switching costs on user resistance to enterprise systems implementation," IEEE Transactions on Engineering Management, Vol. 58 No. 3, pp. 471-482.

Kinzie, M. B., Delcourt, M. A. B., \& Powers, S. M. (1994). Computer technologies: Attitudes and self-efficacy across undergraduate disciplines. Research in Higher Education, 35, 745-768.

Legris, P., Ingham, J., \& Collerette, P. (2003). Why do people use information technology? A critical review of the technology acceptance model. Information \& Management, 40, 191-204

Li, Y., Duan, Y., Fu, Z., \& Alford, P. (2012). An empirical study on behavioral intention to reuse e-learning systems in rural China. British Journal of Educational Technology, 43(6), 933-948.

Liao, H.L., \& Lu, H.P. (2008). The role of experience and innovation characteristics in the adoption and continued use of e-learning websites. Computers and Education, 51(4), 1405-1416.

Liaw, S. S., Huang, H. M., \& Chen, G.D. (2007). Surveying instructor and learner attitudes towards e-learning. Computers \& Education, 49, 1066-1080.

Lim, C. K. (2000). Computer self-efficacy, academic self-concept and other factors as predictors of satisfaction and future participation of adult learners in Web-based distance education. Dissertation Abstracts International, 61, 02A (UMI No. 9962612).

Lin, H. F. (2011). An empirical examination of mobile banking adoption: The effect of innovation attributes and knowledge-based trust. International Journal of Information Management, 31, 252-260.

Lohm"oller, J.-B. (1989). Latent variable path modeling with partial least squares. Heidelberg: Physica-Verlag.

Malle, B.F. and. Knobe J, "The folk concept of intentionality," Journal of Experimental Social Psychology, (33:2), 1997, pp. 101-121.

Marfo, J. S., \& Okine, R. K. (2010). Implementation of e-Learning in Ghanaian Tertiary Institutions (A Case Study of KNUST).

Marfo, J. S., \& Okine, R. K. (2010). Implementation of e-Learning in Ghanaian Tertiary Institutions (A Case Study of KNUST).

Martilla, J. A., \& James, J. C. (1977). Importance-performance analysis. Journal of Marketing, 41(1).

Martins, L.L., and Kellermanns, F.W. (2004), "A model of business school students' acceptance of a web-based course management system," Academy of Management Learning \& Education, Vol. 3 No. 1, pp. 7-26.

Mohammadi, H. (2015). Investigating users' perspectives on e-learning: An integration of TAM and IS success model. Computers in Human Behavior, 45, 359-374.

Morris, M.G. and Venkatesh, V. (2010), "Job characteristics and job satisfaction: understanding the role of enterprise resource planning system implementation,” MIS Quarterly, Vol. 34 No. 1, pp. 143-161.

Myers, J. (1999). Measuring customer satisfaction: Hot buttons and other measurement issues. Chicago: American Marketing Association.

Ong, C. S., \& Lai J. Y. (2006). Gender differences in perceptions and relationships among dominants of elearning acceptance. Computers in Human Behavior, 22(5), 816-829.

Park N., Roman R., Lee S., \& Chung, J. E. (2009). User acceptance of a digital library system in developing countries: An application of the Technology Acceptance Model. International Journal of Information Management, 29(3), 196-209.

Pikkarainen, T., Pikkarainen, K., Karjaluoto, H., Pahnila, S., 2004, "Consumer acceptance of online banking: an extension of the technology acceptance model," Internet Research, Vol. 14, No. 3, pp. 224-235.

Pituch, K. A., \& Lee, Y.-K. (2006). The influence of system characteristics on e-learning use. Computers \& Education, 47, 222-244.

Preacher, K. J., \& Hayes, A. F. (2004). SP SS and SAS procedures for estimating indirect effects in simple mediation models. Behavior Research Methods, Instruments, and Computers, 36, 717-731.

Ringle, C. M., Ringle, C. M., Sarstedt, M., \& Sarstedt, M. (2016). Gain more insight from your PLS-SEM results: The importance-performance map analysis. Industrial Management \& Data Systems, 116(9), 1865-1886.

Roca, J. C., \&Gagne', M. (2008). Understanding e-learning continuance intention in the workplace: Aselfdetermination theory perspective. Computers in Human Behaviour, 24, 1585-1604. 
Saadé, R. G., Nebebe, F., \& Tan, W. (2007). The viability of the technology acceptance model in multimedia learning environments: Comparative study. Interdisciplinary Journal of Knowledge and Learning Objects, $37,175-184$.

Sambrook, S. (2003). E-learning in small organizations. Education+ Training, 45(8/9), 506-516.

Selwyn, N. (2007). The use of computer technology in university teaching and learning: a critical perspective. Journal of Computer Assisted Learning 23 (2), 83-94. doi:10.1111/j.1365-2729.2006.00204.x.

Sosik, J. J., Kahai, S. S., \& Piovoso, M. J. (2009). Silver bullet or voodoo statistic? A premier for using the Partial Least Squares data analytic techniques in group and organization research. Group \& Organization Management, 34(1), 5-36.

Tagoe, M. (2012). Students' Perceptions on Incorporating E-Learning into Teaching and Learning at the University of Ghana. International Journal of Education and Development using Information and Communication Technology, 8(1), 91-103.

Tan, M., \& Teo, T. S. H. (2000). Factors influencing the adoption of Internet banking. Journal of the Association for Information System, 1 (5). Retrieved March 10, 2016 Available from: www.jais.aisnet.org/articles/ default.asp?vol=1\&art=5.

Tarhini, A., El-Masri, M., Ali, M., \& Serrano, A. (2016). Extending the UTAUT model to understand the customers' acceptance and use of internet banking in Lebanon: A structural equation modeling approach. Information Technology and People, 29(4), 830-849. https://doi.org/10.1108/ITP-02-2014-0034

Taylor, S., \& Todd, P. A. (1995). Understanding information technology usage: A test of competing models. Information systems research, 6(2), 144-176.

Teo, T., \& Khine, M. S. (2009). Modeling educational research: The way forward. In T. Teo \& M. S. Khine (Eds.), Structural equation modeling in educational research: Concepts and applications (pp. 3-10). Rotterdam, the Netherlands: Sense Publishers.

Urbach N, \& Ahlemann F., (2010). Structural equation modeling in information systems research using partial least squares. Journal of Information Technology Theory and Application, Vol. 11, No. 2, pp. 5-40.

Van Raaij, E. M., \& Schepers, J. J. (2008). The acceptance and use of a virtual learning environment in China. Computers \& Education, 50(3), 838-852.

Venkatesh, V., \& Davis, F. D. (2000). A theoretical extension of the technology acceptance model: Four longitudinal field studies. Management Science, 46(2), 186-204

Venkatesh, V., Morris, M. G., Davis, G. B., \& Davis, F. D. (2003). User acceptance of information technology: Toward a unified view. MIS Quarterly, 27(3), 425-478.

Wang, Y. S., \& Liao, Y. W. (2008). Assessing e-Government systems success: A validation of the Delone and Mclean model of information systems success. Government Information Quarterly, 25(4), 717-733.

Webster, J., \& Hackley, P. (1997). Teaching effectiveness in technology-mediated distance learning. Academy of Management Journal, 40(6), 1282-1309.

Wright, S. (1918). On the nature of size factors. Genetics, 3, 367-374.

Yang, H. D., \& Yoo, Y. (2004). It's all about attitude: Revisiting the technology acceptance model. Decision Support Systems, 38(1), 19-31.

Zhang, Y., Fang, Y., Wei, K. K., \& Wang, Z. (2012). Promoting the intention of students to continue their participation in e-learning systems: the role of the communication environment. Information Technology \& People, 25(4), 356-375. 